\title{
METODYKA EDUKACJI OSÓB W STARSZYM WIEKU. PODSTAWOWE WSKAZÓWKI I ZASADY
}

Streszczenie: W artykule podjęto temat metodyki nauczania osób w starszym wieku w zakresie: planowania zajęć, określania ich celów, metod, treści, przyswajania wiedzy oraz oceny postępów uczenia się. Szczególną uwagę poświęcono sformułowanym zasadom nauczania seniorów.

Słowa kluczowe: starość, osoby w starszym wieku, nauczanie, metodyka, zasady dydaktyczne, edukacja w starszym wieku, geragogika, gerontologia

Gwałtowne tempo cywilizacyjnego postępu sprawia, że świat zastany w okresie dzieciństwa znacząco różni się od tego, w którym przychodzi żyć w okresie dorosłości i niemal w niczym nie przypomina go na starość. Współcześnie tradycyjny podział cyklu życia na etapy: młodość - szkoła, dorosłość - praca, starość - czas wolny, przestaje znajdować zastosowanie. Pojawia się potrzeba przearanżowania kontinuum życia ludzkiego w taki sposób, aby umożliwić na jego różnych odcinkach wyjścia i powroty do edukacji i pracy zawodowej. W koncepcji tej uczenie się zostaje rozciągnięte na całe życie i staje się imperatywem, jeśli osoba ma radzić sobie z eksplozją wiedzy, informacji i nowoczesnych technologii, rozumieć zmiany społeczne i pomyślnie adaptować się do własnego starzenia się. Podstawą sprawnego funkcjonowania we współczesnym świecie staje się nauka trwająca całe życie, prowadzona w trybie samokształcenia oraz w ramach formalnej edukacji. Wypływa stąd wzrastająca rola andragogiki skierowanej do osób dorosłych oraz geragogiki, specjalizującej się w edukacji osób starszych, obu opartych na idei uczenia się przez całe życie.

Jeszcze do niedawna nie dostrzegano potrzeby nauki w starszym wieku, wobec czego seniorzy znajdowali się poza głównym nurtem zainteresowania pedagogiki. W obecnej dobie starzenia się społeczeństw osoby dorosłe i starsze stanowią w edukacji najszybciej powiększający się segment wiekowy uczestników. Z pedagogiki i andragogiki wyłania się odrębna dyscyplina - geragogika, funkcjonująca pod nazwą gerontologia edukacyjna, pedagogika starzenia się, geriagogika czy też gerontagogika (Lemieux, Martinez 200o). Formalnie powstała w połowie XX wieku, obecnie przeżywa swój rozkwit. Geragogika zajmuje się nauczaniem, uczeniem się i wychowywaniem osób w starszym wieku, w kontekście prawidłowej adaptacji do starości, jednak z użyciem innych metod, narzędzi i środków niż pedagogika (Zych 1999). Zwraca uwagę na różnice w uczeniu się osób starszych w porównaniu z osobami młodszymi. Jak oczywista wydaje się konieczność dostosowania nauczania do specyficznych potrzeb dzieci w wieku przedszkolnym, szkolnym czy młodzieży, tak niedoceniona pozostaje kwestia przystosowania nauczania do unikalnych 
potrzeb i zainteresowań osób w starszym wieku. Uboga metodyka nauczania tej grupy wiekowej wynika ze stosunkowo niewielkiej wiedzy na temat rozwoju człowieka sięgającego lat jego starości. Osoby starsze wciąż z trudem postrzegane są jako jednostki uczące się, choć, jak dowiedziono, po przystosowaniu metodyki nauczania do ich specyficznych uwarunkowań, możliwości i potrzeb, są w stanie osiągać takie same wyniki jak osoby młodsze (Tomporowski 2003). Uczenie się nie podlega starzeniu.

\section{Specyfika pracy edukacyjnej z osobami w starszym wieku}

Podstawą efektywnej pracy z osobami w starszym wieku jest szeroka znajomość prawideł ich fizycznego, psychicznego, duchowego, społecznego czy funkcjonalnego rozwoju, pozwalająca na trafne określenie ich rzeczywistych możliwości i potrzeb, również w dziedzinie edukacji. Jednocześnie należy mieć na uwadze ogromne zróżnicowanie wewnętrzne tej grupy wiekowej, wymagające dostosowywania wszelkich metodycznych zaleceń i wskazówek do danej kohorty, zespołu i jednostek.

\section{Planowanie zajęć}

Uczenie się cechuje spontaniczność, z kolei edukacja, jako zaplanowane uczenie oparte na uprzednio zaprojektowanym programie, przewiduje efekty podjętych działań. Praca edukacyjna $z$ osobami $w$ starszym wieku rozpoczyna się od jej zaplanowania, czyli na długo przed pierwszym spotkaniem. Zajęcia wymagają organizacji przeprowadzonej z największą starannością i dokładnością. To etap najtrudniejszy, ale najważniejszy. Wszystkie późniejsze działania, być może bardziej rozciągnięte w czasie, będą stanowić realizację wcześniej podjętych zamierzeń, realizację tym sprawniejszą, im dokładniej i lepiej została zaplanowana. Na etapie wykonawczym wyklucza się wdrażanie radykalnych zmian i pomysłów, a nadmierna spontaniczność wróży chaos i porażkę w osiąganiu wyznaczonych celów edukacyjnych. Etap planowania wieńczy wypracowanie precyzyjnej i spójnej koncepcji szkolenia, nauczania i uczenia się.

W pracy edukacyjnej z osobami w starszym wieku planowanie można podzielić na dwa etapy. W pierwszej kolejności planowanie dokonywane jest samodzielnie przez instruktora, w następnej wymaga zaangażowania samych uczestników, w określonym zakresie współdecydujących w kwestii własnej edukacji i, tym samym, współodpowiedzialnych za jej efekty. Z perspektywy instruktora podstawą dobrego planowania jest dokładne poznanie członków edukacyjnej grupy - cele i metodyka nauczania opiera się na ich rozpoznanych możliwościach i ograniczeniach, zdolnościach i zainteresowaniach. Program zajęć wymaga ustalenia: celu głównego i celów operacyjnych, treści kształcenia, metod realizacji celów, środków dydaktycznych, sposobów kontroli efektów, zalecanej literatury przedmiotu i ćwiczeń utrwalających.

Aby podejmowane działania edukacyjne nie były chaotyczne, powinny być podporządkowane wcześniej określonym celom. To świadomie założone efekty kształcenia, które stanowią podstawę dla określania metod kształcenia, treści czy sposobów monitorowania postępów w nauczaniu i oceny jego skuteczności. Wyznacza się cele dla całego szkolenia oraz cele szczegółowe dla każdej jednostki dydaktycznej. Cele należy odnosić do zmian, jakie planuje się osiągnąć w kategoriach wiedzy, umiejętności czy kompetencji uczestników. 
Celem samym w sobie nie jest prezentacja określonego materiału, wykonanie jakichś ćwiczeń czy zadań, ale ich wpływ na osoby uczące się. Ten wpływ należy przewidzieć i zaplanować.

\section{Metody pracy}

Osoby starsze mogą preferować bardziej ustrukturyzowane strategie uczenia się, ale po osiągnięciu pewnego poziomu wiedzy i motywacji oraz odpowiedzialności za własne uczenie się i umiejętności w tej dziedzinie, wybierają już mniej ustrukturyzowane podejście do nauki (Delahaye, Smith 1998). Początkowo oczekują, a nawet pragną tradycyjnych metod nauczania (Spigner-Littles, Anderson 1999), później doceniają inne metody uczenia się, choć należy zaznaczyć, że wykład znajduje się wciąż na szczycie preferowanych przez nich metod prezentacji materiału (Brady i in. 2003). Mimo że tak bardzo krytykowany jako metoda nauczania-uczenia się, wykład sprawdza się znakomicie w pracy z osobami w starszym wieku (Knowles 1980). Seniorzy chcą nadal uczyć się i przygotowywać się do zajęć, czytając książki i materiały naukowe (Simson i in. 2001).

Wysoka motywacja uczących się seniorów, bogate życiowe doświadczenie oraz dojrzałe interpersonalne umiejętności dają solidną podstawę dla prowadzenia w tej kategorii wiekowej ćwiczeń praktycznych, np. w zespołach dyskusyjnych, projektach grupowych. Dobrze jest stosować nauczanie bezpośrednie, np.: trening, demonstrację, studium przypadku, inscenizację, prace ręczne, obserwację. Zasadą będzie tu: widzieć, słyszeć i dotykać. Należy zwrócić uwagę na metody aktywizujące, np. wyprawy w teren wykorzystujące element przygody (Kilian 2014), jak również metody autobiografii i reminiscencji. Zasadą jest indywidualne dopasowanie metod nauczania do potrzeb określonej grupy uczestników.

\section{Tematyka zajęć}

Tematyka zajęć wynika z postawionych celów uczenia się oraz preferencji uczestników. Niemniej nawet jeśli edukacja związana jest $\mathrm{z}$ dokształcaniem zawodowym i zdobywaniem instrumentalnej wiedzy i umiejętności, istnieją tematy powracające podczas grupowych zajęć z osobami starszymi, które warto podjąć, jeśli nauczanie ma być zintegrowane $\mathrm{z}$ doświadczeniem życiowym uczestników w starszym wieku i ich rzeczywistymi potrzebami. Zazwyczaj są to tematy poważne aniżeli rekreacyjne (Simson, Thompson, Wilson 2001). Wiadomo również, że kobiety bardziej preferują nauki humanistyczne, mężczyźni zaś przyrodnicze (Halicki 200o). Do najpopularniejszych wśród seniorów zagadnień należą:

- łączność z przeszłością - opowiadanie o własnym życiu, osiągnięciach, trudnościach, co pozwala zapamiętać minione wydarzenia, przemyśleć je, scalić, nadać im ponadczasowe znaczenie, odkryć sens życia;

- rozumienie nowoczesnego świata - kwestia dostosowania się do życia w świecie, który radykalnie zmienił się od czasów dzieciństwa i młodości;

- choroby i niepełnosprawność - obawa przed utratą samodzielności życiowej;

- śmierć - utrata członków rodziny i przyjaciół dotyczy tematu szeroko pojmowanej straty właściwej wiekowi starszemu;

- rodzina - opowieści o współmałżonkach, dzieciach i wnuczętach - skupianie się na rodzinie może wynikać z utraty innych społecznych i zawodowych ról; 
- samotność - potrzeba pozostawania $\mathrm{w}$ relacji z innymi, poznawania nowych znajomych;

- finanse - kwestie kosztów utrzymania, leczenia;

- przekonania religijne, kwestie sensu życia;

- zagospodarowanie czasu wolnego i obszaru zainteresowań.

Zaleca się oszczędność tematyczną - materiał będzie lepiej przyswojony, jeśli obejmie zadania proste, ograniczoną liczbę prezentowanych zagadnień, a informacje skupią się wokół silnie zaznaczonego punktu centralnego. Na początku zajęć można zapoznać uczestników z głównymi punktami spotkania lub przekazać sylabus zajęć, stanowiący „mapę spotkań” z jasno wyznaczonymi celami.

\section{Przyswajanie treści}

Omawianie i przyswajanie treści powinno odbywać się w następującym porządku: od rzeczy pilnych do odległych, od znanego do nieznanego, od łatwego do trudnego, od przykładów do abstrakcji, od prostego do złożonego. Podejmowane zagadnienia wymagają wysoce uporządkowanej i logicznej prezentacji, zawierającej zapowiedzi, wyliczenia, powtórzenia i podsumowania. Zaleca się przekazywać treści prostym, zrozumiałym językiem, bez zbędnej terminologii, komentarzy i dygresji, dostarczać jasnych, krótkich instrukcji, a przykłady formułować w sposób nieporuszający spraw nieistotnych, bliski doświadczeniom uczestników. Można rozważyć zadawanie krótkich, stymulujących myślenie prac domowych.

Szybkie tempo pracy działa na niekorzyść osób starszych. A zatem nie należy wywierać presji czasowej, a promować naukę we własnym rytmie. Odpowiednie tempo pracy służyć ma swobodnemu i skutecznemu nabywaniu wiedzy i umiejętności. Warto zapewnić odpowiednio długi czas na przebieg wszystkich ważnych etapów uczenia się, łącznie z dyskusją i udzielaniem odpowiedzi na pytania, jak również czas na przerwę i odpoczynek. Częste przerwy służą m.in. rozładowaniu napięcia towarzyszącemu uczeniu się, odpoczynkowi, jak również, co istotne, wygenerowaniu przestrzeni do nawiązywania społecznych relacji.

Osoby starsze często nie posiadają dużego doświadczenia w uczeniu się, dlatego należy wspierać ich wiarę we własną zdolność do nauki i pokierować w procesie przyswajania wiedzy i umiejętności, np. uczyć: jak przetwarzać nabywane informacje, jakie stosować techniki zapamiętywania, jak sporządzać notatki, jak wiązać nowe pojęcia $\mathrm{z}$ własnym doświadczeniem. Zadaniem instruktora jest pomóc seniorom w rozwijaniu zdolności uczenia się i nabywaniu w nauce osobistych kompetencji.

W porównaniu z osobami młodymi seniorzy używają mniej skutecznych metod uczenia się, jak np. mnemotechnik (Whitbourne, Slevin 1978), dlatego w ich przypadku dużą rolę odgrywają uzdolnienia wyjściowe oraz dostosowany do wieku sposób nauczania. Starsze osoby mogą potrzebować więcej czasu na przyswojenie nowych umiejętności, zwłaszcza wymagających długotrwałej pamięci. Z tego powodu warto powtarzać podawane informacje, prowadzić zeszyt spotkań, przekazywać spisane instrukcje, które uczestnik będzie mógł sobie później, w razie potrzeby, przypomnieć. Lepszemu zapamiętaniu materiału służy również unikanie długiej, nieprzerwanej prezentacji oraz częstsze, ale krótsze sesje szkoleniowe, dokonywanie podsumowań. Kiedy informacja jest już przyswojona, starsza osoba będzie pamiętać ją skutecznie, prawdopodobnie tak samo dobrze jak osoba młodsza. 
Ocena postępów w uczeniu się

W ocenie efektów kształcenia osób starszych nie chodzi o formalne oceny, świadectwa, dyplomy, które w tej grupie wiekowej mogą tylko zniechęcać do podjęcia nauki. Ważny staje się tu subiektywny pogląd uczestnika na temat własnych postępów w uczeniu się. Wykorzystywać można ponadto różnego rodzaju recenzje, ocenę rówieśniczą oraz informacje zwrotne dostarczane przez instruktora oraz współuczestników.

Należy ograniczyć wykonywanie typowych testów, pamiętając, że podczas nauki osoby w dojrzałym wieku stale oceniają samych siebie. Jeśli jednak testy są wymagane, seniorów należy zapoznać $\mathrm{z}$ celem i sposobem ich rozwiązywania, ponieważ, w odróżnieniu od młodszych pokoleń uczniów, nie mają w tej dziedzinie doświadczenia i mogą uzyskiwać gorsze wyniki. Poza tym testy wymagają dostosowania do specyfiki funkcjonowania psychologicznego osób starszych, np. z uwagi na trudności z przywoływaniem informacji z pamięci, ale za to lepszym ich rozpoznawaniem, pytania zamknięte minimalizują ryzyko błędu. Wiadomo również, że osoby starsze mają mniejsze trudności z udzieleniem odpowiedzi na pytania zaprezentowane wzrokowo w porównaniu z prezentacją słuchową (Park 1999). Wyrazem adaptacji do wolniejszego tempa pracy będzie wydłużenie czasu przewidzianego na wykonanie testów. W razie potrzeby należy dostarczyć testy pisane powiększoną czcionką. Uczestnicy powinni zostać uprzedzeni o możliwości przyniesienia na czas wykonywania testu wykorzystywanych pomocy rehabilitacyjnych, np. lup, okularów, aparatów słuchowych. Nie można zapomnieć o stworzeniu odpowiedniego otoczenia - dobrze oświetlonego, ale niewywołującego olśnień, cichego, spokojnego. Testy mają być krótkie, a w przypadku dłuższych warto przewidzieć przerwę na odpoczynek lub toaletę. Ocena wyników nie może być ani zbyt rygorystyczna, ani nadmiernie pobłażliwa.

Osoby starsze doświadczają w swoim życiu wielu strat i zakończenie ważnych dla nich zajęć edukacyjnych lub terapeutycznych może być postrzegane jako kolejna $\mathrm{z}$ nich. Z tego powodu na ostatnim etapie można rozciągać czas między spotkaniami, zachęcać uczestników do nieformalnych kontaktów między sobą, wymiany adresów i telefonów. Po zakończeniu zajęć grupa może dalej się spotykać w domu prywatnym lub kawiarni, już bez instruktora. Można zorganizować sesje uzupełniające, podczas których instruktor sprawdza, na ile uczestnicy posługują się nabytymi wiadomościami i sprawnościami oraz w jaki sposób i kiedy je wykorzystują.

\section{Zasady pracy edukacyjnej z osobami w starszym wieku}

Zasady w działalności dydaktycznej, nauczycielskiej czy szkoleniowej to pewne drogowskazy ukierunkowujące na optymalny dla danych uczestników tor uczenia się i wzmacniające jego efektywność. Zaprezentowane poniżej odpowiadają specyfice uczenia się w starszym wieku i nauczania seniorów. Zasady pracy edukacyjnej z osobami w starszym wieku stanowią podstawę metodyki ich nauczania i zapewniają lepszą realizację celów kształcenia. Pozwalają na prowadzenie ustrukturyzowanych i zaplanowanych działań wspierających tę naturalną dla każdego wieku umysłową aktywność.

Zdaniem Malcolma Knowlesa (Knowles i in. 2009) motywacja dorosłych do uczenia się zależy od ich przekonania, że:

- w uczeniu się będą mogli odnieść powodzenie (sukces); 
- będą mieli wpływ na proces uczenia się, co wyzwala w nich wolę do osiągania wyznaczonych celów, nawet po zakończeniu formalnych zajęć (wola);

- uczą się ważnych i potrzebnych w realnym życiu rzeczy (wartość);

- z uczenia się będą czerpać przyjemność (przyjemność).

O motywacji dorosłych do nauki decyduje przekonanie, że są w stanie przyswoić sobie nowe treści i umiejętności (sukces), współdecydować o kształcie i treści podjętej edukacji (wola), odnieść z niej konkretne korzyści do wykorzystania w praktyce życia codziennego (wartość) oraz czerpać satysfakcję (przyjemność). Powyższym czynnikom można przyporządkować następujące zasady nauczania osób starszych:

- sukces - zasada indywidualizacji i zasada kompensacji;

- wola - zasada aktywizacji i zasada samokierowania w procesie uczenia się;

- wartość - zasada wykorzystania życiowego doświadczenia oraz zasada użyteczności przyswajanej wiedzy i umiejętności;

- przyjemność - zasada wzajemnego szacunku, zasada pozytywnej satysfakcji oraz zasada inkluzji.

Oczywiście powyższe zasady przenikają się i są wzajemnie powiązane, np. zasada indywidualizacji decydująca o sukcesie podjętej edukacji w pewnej mierze odpowiada również na potrzebę współdecydowania w zakresie jej treści i przebiegu (wola), z kolei wcielona w życie zasada wykorzystania życiowego doświadczenia (wartość) istotnie wspiera aktywizację uczestników (wola). Wszystkie zasady przyporządkowane sukcesowi, woli i wartościom znacząco wpływają na przyjemność czerpaną z nauki. Stosowanie wymienionych zasad zapewnia natomiast sukces w nauczaniu osób starszych.

\section{Zasada indywidualizacji}

Populacja osób starszych tworzy najbardziej zróżnicowaną wewnętrznie kategorię wiekową (Jarvis 2001). Z biegiem czasu wzmocnieniu ulegają różnice indywidualne wynikające $\mathrm{z}$ długiej i niepowtarzalnej w wymiarze fizycznym i psychicznym historii życia, przebiegającej w unikalnym społeczno-kulturowym kontekście. Człowiek staje się coraz bardziej wyjątkowy również w dziedzinie uczenia się, własnych umiejętności, możliwości, potrzeb, zgromadzonej wiedzy i doświadczenia. Poznanie, zrozumienie i dostosowanie nauczania do indywidualnych różnic zachodzących między osobami w zaawansowanym wieku stanowi podstawę jego efektywności. Generalizacje, na których w dużej mierze opiera się metodyka, w tej populacji wymagają ostrożnego stosowania. Brak tu miejsca na rutynę i pewne posługiwanie się sprawdzonymi rozwiązaniami. Ogromna wewnętrzna różnorodność najstarszej kategorii wiekowej uczących się osób w procesie nauczania wymaga elastyczności w zakresie: celów, metod, narzędzi, pomocy dydaktycznych, sposobu prowadzenia zajęć, sposobów komunikowania się, adaptacji otoczenia fizycznego. Warunkiem powodzenia pracy edukacyjnej z seniorami jest szeroka znajomość specyfiki ich biopsychospołecznego funkcjonowania, a także unikalnych potrzeb i możliwości.

\section{Zasada kompensacji}

W pracy edukacyjnej z osobami w starszym wieku zasadnicze znaczenie posiada elastyczność względem ich potrzeb i umiejętności, wynikających zarówno ze specyfiki umysłowego 
i fizycznego funkcjonowania poszczególnych jednostek, naznaczonego skutkami naturalnego i patologicznego starzenia się, ale także z kontekstu historyczno-kulturowego, w jakim wzrastały poszczególne kohorty. Metodyka zajęć powinna być dostosowana do naturalnych, fizycznych i psychicznych, uwarunkowań seniorów, np. zmian sensorycznych czy trudności w wykorzystywaniu pamięci krótkoterminowej. Kompensacja polega również na uwzględnianiu mniejszego edukacyjnego doświadczenia obecnego pokolenia seniorów i wzmacnianiu np. umiejętności zapamiętywania (mnemotechniki) czy sporządzania notatek, wcale nieoczywistych dla osób, które zakończyły swoją edukację pół wieku temu, nierzadko na kilku klasach szkoły podstawowej.

W głównej mierze jednak zasada kompensacji odnosi się do wyrównywania edukacyjnych szans seniorów poprzez przezwyciężanie ograniczeń sprawności fizycznej, psychicznej i umysłowej wynikających z doświadczanej w starszym wieku niepełnosprawności. Zasada ta wymaga konieczności dostosowania otoczenia, środków i pomocy dydaktycznych do możliwości niepełnosprawnych uczestników, np. poprzez wykorzystywanie materiałów z powiększoną czcionką z uwagi na słabowzroczność, ustawianie miejsc siedzących na planie koła w celu optymalizowania warunków dla zdolności widzenia i słyszenia, wzmacnianie komunikacji pozawerbalnej w kontakcie z osobami z demencją. Wolniejszy w przypadku seniorów czas reakcji nie może budzić reakcji ponaglania, będącej przyczyną frustracji i spadku motywacji. Instruktor powinien przyjąć postawę pozytywną i wspierającą.

Niedocenianą kwestią jest czas i miejsce spotkań. Z uwagi na bezpieczeństwo i lepsze funkcjonowanie seniorów dzienne spotkania zwykle są chętniej akceptowane niż spotkania wieczorne, choć i tutaj istnieją indywidualne różnice spowodowane np. porą przyjmowania lekarstw wywołujących negatywne skutki uboczne jak senność, poczucie słabości czy zawroty głowy. W przypadku ludzi w zaawansowanym wieku wybór miejsca spotkań jest sprawą wielkiej wagi i może istotnie wpływać na decyzję o ich udziale w zajęciach. Planując zajęcia, należy rozważyć odpowiednie miejsce spotkań pod kątem możliwości dotarcia do niego, cech samego budynku oraz jego otoczenia. Należy wziąć pod uwagę dostępność różnych środków transportu (na spotkania i po spotkaniach), przeanalizować możliwości zaparkowania auta, odległość i oświetlenie drogi z parkingu do budynku, rozkład jazdy autobusu, odległość przystanku od budynku. Dla seniorów ważną kwestią jest bezpieczeństwo - bezpieczna okolica, bezpieczna droga do budynku tak przed zajęciami, jak i po ich zakończeniu, zwłaszcza jeśli odbywają się wieczorową porą, a w okresie jesienno-zimowym po zmroku.

Zajęcia powinny przebiegać w wygodnym, dostosowanym do potrzeb osób niepełnosprawnych miejscu. W ocenie budynku bierze się pod uwagę m.in.:

- dostępność dla osób niepełnosprawnych ruchowo (np. podjazdy);

- liczbę schodów do przebycia;

- obecność poręczy, windy;

- nawierzchnię (czy będzie śliska w okresie jesienno-zimowym, brak wystających dywanów, przewodów itp.);

- bliskość łazienki dostosowanej do potrzeb osób niepełnosprawnych (częste wśród seniorów trudności z trzymaniem moczu);

- dobre oświetlenie.

Same pomieszczenia natomiast ocenia się m.in. pod kątem: 
- umeblowania (np. stabilne, wysokie krzesła, najchętniej z oparciami i poręczami, z których łatwo się podnieść);

- rozmieszczenia uczestników (np. stoły możliwe do łatwego przearanżowania i ustawienia w kole, na planie litery U czy kwadratu);

- bezpieczeństwa (np. brak ostrych kantów stołów, wystających kabli, niestabilnych chodników);

- oświetlenia (np. preferencja światła dziennego, ale unikanie olśnień dzięki zastosowaniu zasłon czy rolet w oknach);

- zakłóceń i hałasu (np. troska o dobrą akustykę, zamykanie drzwi, ewentualnie okien);

- temperatury i wentylacji (np. osoby starsze preferują wyższą temperaturę);

- przestrzeni na pomoce rehabilitacyjne (miejsce na odstawienie wózka czy odłożenie lasek).

\section{Zasada aktywizacji}

Tradycyjna edukacja koncentruje się wokół nauczyciela jako zawiadującego tym procesem. On jest ekspertem i dyspozytorem wiedzy przekazywanej uczniom, zwykle w formie wykładu, pokazu slajdów czy filmu. Rolą ucznia jest słuchać, zadawać pytania i pasywnie przyswajać wiedzę. W zaawansowanym wieku jednak uczenie się jest bardziej efektywne, kiedy wiedza jest samodzielnie konstruowana, a nie biernie absorbowana. Badania wykazały (Vakil i in. 1998), że u starszych osób aktywne uczenie się prowadzi do lepszego wykonywania trudnych zadań aniżeli uczenie się pasywne. Skutki aktywnego nauczania i uczenia się wydają się również bardziej długotrwałe.

Kiedy uczeń postawiony jest w centrum procesu uczenia, zmienia się rola nauczyciela, który rezygnuje z funkcji kierowniczej i mentorskiej, a przyjmuje postawę animatora i moderatora. Jako animator jest tym, który ożywia pokłady posiadanej przez seniorów wiedzy, mądrości i doświadczenia i pobudza do aktywności w ich wzbogacaniu. Jako moderator czujnie steruje procesem uczenia się i koordynuje nim. Jego głównym zadaniem staje się aktywizowanie seniorów na etapie planowania edukacji (np. określanie jej celów, treści), przebiegu edukacji (tj. przyswajania wiedzy i umiejętności), monitoringu edukacji (wskazywanie na dokonany postęp i osiągnięcia) oraz samoedukacji (samodzielnie podjętej nauki). Zasada aktywizacji wykracza poza etap edukacyjnych zajęć prowadzonych pod kierunkiem nauczyciela, będących tylko wsparciem i katalizatorem wyzwalającym pragnienie i umiejętność samodzielnego uczenia się. W dłuższej perspektywie służy wypracowaniu umiejętności prowadzenia samoedukacji.

Zadaniem nauczyciela staje się pobudzanie seniorów do aktywnego udziału w zajęciach poprzez: stwarzanie okazji do dzielenia się własnymi przemyśleniami, zgromadzoną wiedzą i doświadczeniem, zadawanie pytań wzbudzających ciekawość i refleksję, skłaniających do myślenia oraz zachęcanie do samodzielnego ich stawiania, kreślenie problemów do rozwikłania. W modelu tym uczenie staje się interaktywne, wspierane takimi technikami pracy jak: odgrywanie ról, studium przypadku czy praca w małych grupach (Tabbutt-Henry i in. 2008). Instruktor wskazuje na źródła informacji, takie jak biblioteki, uniwersytety, centra seniorów, udostępnia materiały do samodzielnego uczenia się, pomaga tworzyć sieci wymiany wiedzy i grupy wsparcia dla uczących się seniorów. Osoby starsze, często początkowo niepewne i wycofane, włączane są w przebieg zajęć, zyskują możliwość 
samokierowania w aktywnym uczeniu się i osiągnięcia w tej dziedzinie samodzielności. Służy temu redukowanie zależności uczącego się od instruktora oraz promowanie osobistej odpowiedzialności i wewnętrznej motywacji.

\section{Zasada samokierowania w procesie uczenia się}

Osoby starsze przywykły do sprawowania kontroli nad własnym życiem, również w dziedzinie uczenia się. Szacuje się, że w przypadku osób dorosłych około 70\% nauki dokonuje się w trybie samokształcenia (Lamdin 1997). Podobnej samodzielności i możliwości współdecydowania seniorzy oczekują od formalnej edukacji. Wykazano, że w tej grupie wiekowej nauczanie jest bardziej efektywne, jeśli osoby są zaproszone do udziału w planowaniu szkolenia w zakresie celów, środków, metod itp. (Spigner-Littles, Anderson 1999). Ważnym zadaniem nauczyciela staje się rozbudzanie u seniorów ciekawości świata, zamiłowania do uczenia się i pragnienia podejmowania niezależnych studiów. Osoby starsze, często z powodu ubogich edukacyjnych doświadczeń i stereotypowych społecznych przekonań na temat zdolności umysłowych w tym wieku, nie są świadomi własnego edukacyjnego potencjału. Z drugiej strony nauczyciele mogą traktować samokierowanie uczestników jako zagrożenie dla własnego autorytetu. Wspieranie samodzielności edukacyjnej zaawansowanych wiekowo uczestników wymaga od nich odrzucenia autorytarnej pozycji władzy i podjęcia partnerskiego stylu współpracy. Znajduje to odzwierciedlenie również w warstwie lingwistycznej, gdzie nauczyciel osób dorosłych określany jest mianem edukatora, trenera czy doradcy.

W edukacji osób starszych nauczanie i uczenie się mogą być czynnościami zamiennymi. W tym okresie życia zniesione są granice między życiem a nauką, edukacją a doświadczeniem, studiowaniem a socjalizacją (Percy, Withnall 1994). Z wiekiem ludzie coraz mocniej wierzą we własną zdolność do planowania i prowadzenia samokształcenia, mniej polegają na zewnętrznych autorytetach. Dorośli uczą się efektywnie poprzez samodzielne rozwiązywanie problemów. Sami analizują sytuację, dokonują uogólnień i wyciągają wnioski. Nawet kiedy uczestniczą w formalnych zajęciach, chcą dyskutować, wpływać na ich kształt i przebieg. Nie lubią niespodzianek i nagłych zmian, np. terminu spotkań. Preferują pracę we własnym tempie, bez narzucania sztywnych reguł. Osoby starsze przywykły do kontrolowania własnego życia, a ci, którzy z powodu doznawanych strat (zdrowia, sprawności, pracy, satysfakcjonujących dochodów itp.) wiele z tejże kontroli utracili - tym bardziej powinni być zachęcani do zwiększania poczucia panowania nad własnym życiem. Samodzielność życiowa stanowi ostateczny cel pedagogiki, również w odniesieniu do starości, a zasada samokierowania w procesie edukacji bezpośrednio ją wspiera.

\section{Zasada wykorzystania doświadczenia życiowego}

W przypadku uczących się seniorów można mówić o bogactwie zgromadzonej w ciągu życia wiedzy i doświadczenia. W zaawansowanym wieku ludzie lubią rozumieć to, czego się uczą, wiązać nowe informacje z praktyką życia codziennego. Siła i emocjonalnego przywiązania do formowanej przez długie lata wiedzy teoretycznej i praktycznej, własnych przekonań i wartości jest tak wielka, że konfrontacja z niepodważalnymi informacjami zaprzeczającymi ich długotrwałym poglądom może spowodować odrzucenie tych 
informacji lub też skłaniać do poszukiwania alternatywnych wyjaśnień (Spigner-Littles, Anderson 1999).

Ronald Sherron i Barry Lumsten (Sherron, Lumsten 1990) uważają, że w nauczaniu osób w starszym wieku należy koncentrować się nie tyle na przekazywaniu informacji, ile na uzyskiwaniu nowego rozumienia dla posiadanej już przez uczących się wiedzy. Odniesienie stanowi tu struktura sokratejskiego dialogu, w którym nauczyciel zadaje pytania w taki sposób, aby uczeń samodzielnie dochodził do kolejnych pokładów wiedzy. Nauczyciel staje się „akuszerką idei”, która pomaga w rodzeniu się mądrości u innych przez zadawanie pytań. Nie ma tu dobrych i złych odpowiedzi - jest życiowe doświadczenie stanowiące punkt wyjścia dla dalszego uczenia się.

W tradycyjnym modelu nauczania wiedza prezentowana jest zanim osoba dowie się, dlaczego miałaby chcieć ją przyswoić. Omawiana zasada przyjmuje osobiste doświadczenie za bazę dla edukacyjnej aktywności osób w starszym wieku, stanowiącą uzasadnienie i jednocześnie motywację dla podjęcia wysiłku uczenia się. Punktem wyjścia jest tu doświadczenie i wiedza uczestników, a nie stan wiedzy i plany nauczyciela. Uczestnik od początku zaangażowany jest w zajęcia, ponieważ czuje subiektywny związek z tematem i rozumie, jak wpływał lub wpływa on na jego życie.

Zasada bazowania w procesie edukacji na życiowym doświadczeniu uczestników w odniesieniu do osób starszych zyskuje dodatkowy terapeutyczny walor. Pozwala wykorzystywać elementy reminiscencji wzmacniającej poczucie wartości zgromadzonych doświadczeń i sensu minionego życia. Praktyka i badania naukowe wykazały, że osoby starsze swobodniej niż młodsze poruszają się między przeszłością a teraźniejszością, a przywoływanie wspomnień stanowi niezbędny element kontynuacji rozwoju w starszym wieku, wzmacnia poczucie tożsamości i spełnienia (Birren, Schaie 2001; Corey 2004). Powracanie do życiowych doświadczeń daje możliwość zintegrowania własnych wspomnień i obrazu samego siebie jako pełnej osoby z kompletną historią życia, odkrycia w niej ponadczasowych znaczeń i wyciągnięcie wniosków. W kontekście uczenia się w starszym wieku zasoby przeszłości to nie bezwartościowe antyki, a edukacyjny kapitał.

\section{Zasada użyteczności przyswajanej wiedzy i umiejętności}

Specyfikę edukacji w starszym wieku znakomicie oddaje konstruktywistyczna teoria uczenia się (Spigner-Littles, Anderson 1999), która mówi, że wiedza jest czymś, co człowiek tworzy dla siebie samego na bazie własnych doświadczeń. Aby uczenie stało się zintegrowaną częścią pamięci, nowe informacje muszą być powiązane z celami uczącego się, jego doświadczeniem, dotychczasową wiedzą, wartościami czy przekonaniami. Informacje, które są po prostu zapamiętywane i niezwiązane z poglądem na świat uczącego się, szybko zostaną zapomniane. Wiedza nie może być transmitowana od instruktora do ucznia, pasywnie oczekującego na przepływ wiedzy. Nauka będzie efektywna, kiedy uczący się uznają przedmiot nauki za ważny w ich życiu.

Zasada użyteczności zwraca uwagę na to, że skuteczność uczenia się ludzi dorosłych i starszych jest większa wówczas, kiedy elementy wiedzy deklaratywnej (jak jest) powiązane są z wiedzą proceduralną (co należy zrobić) i wyjaśniającą (dlaczego). Seniorzy są wyjątkowo pragmatyczni wobec uczenia się. Lubią rozumieć użyteczność przyswajanego materiału, wiedzieć, dlaczego i jak używać nowych informacji, znać powiązanie między 
nową wiedzą, a tym, co już potrafią. Chcą przekładać wiedzę na praktykę, dlatego znacznie chętniej uczą się tego, co uważają za istotne i potrzebne w ich życiu. Chcą rozwiązywać problemy i natychmiast wykorzystywać zdobytą wiedzę. Nie chcą natomiast uczyć się czegoś, co jest dla nich zupełnie nowe i w praktyce zbędne.

W uczeniu wyróżnia się cele ekspresyjne, związane z nauką dla samego siebie i cele instrumentalne związane z zewnętrznymi celami jak kwalifikacje zawodowe. Seniorzy nie przywiązują wagi do zdobywania punktów, stopni, certyfikatów i dyplomów przydatnych w karierze zawodowej, ale nie na emeryturze. Skupiają się na osobistym rozwoju i korzystaniu z wiedzy i umiejętności dla lepszego rozumienia świata, w którym żyją, bez potrzeby poddawania się jakimkolwiek ocenom. Badania potwierdzają, że uczenie się w starszym wieku nie ma związku z certyfikatami ani instrumentalną wartością przyswajanej wiedzy, ale z ekspresyjną motywacją, taką jak: zainteresowania umysłowe, ciekawość intelektualna, osobisty rozwój, satysfakcja czerpana z uczenia się (Jarvis, Walker 1997; Kim, Merriam 2004). Osoby starsze najczęściej pragną uczyć się z wewnętrznych powodów, dla samej wiedzy i satysfakcji, chętnie w towarzystwie innych, szukając okazji do nawiązywania kontaktów społecznych. Dzięki temu szkolenie jest bardziej swobodne i mniej sztywne zadaniowo, osadzone na ciekawości i chęci uczenia się seniorów, dzierżących większą kontrolę nad procesem uczenia się. Koncentrowanie nauki na ważnych aspektach życia i użytecznych celach oznacza konieczność odwoływania się do potrzeb, zainteresowań i doświadczeń uczestników, co z kolei wzmacnia ich aktywność w procesie uczenia się.

\section{Zasada pozytywnej satysfakcji}

Seniorzy zajęcia edukacyjne zazwyczaj rozpoczynają z dużą dozą niepewności wobec własnych umiejętności i trafności decyzji co do podjętego szkolenia, pełni obaw, czy sobie poradzą, często pod ciężarem krytycznej obserwacji bliskich i ich zainteresowania czynionymi postępami w nauce. W procesie uczenia potrzebują oni dowartościowywania i wzbudzania większej wiary we własne zdolności, jak również czerpania z nauki przyjemności i satysfakcji.

Immanuel Kant wyróżniał satysfakcję negatywną i pozytywną. Samozadowolenie (self-contentment) to stan rozpoznawania braku potrzeb lub ignorowania ich, określane mianem negatywnej satysfakcji. Szczęście (happiness) natomiast to coś więcej - to stan zaspokajania dyssatysfakcji związanej ze stanem niezadowolenia.

Zasada pozytywnej satysfakcji podkreśla znaczenie małych sukcesów w edukacji osób w starszym wieku. Realistyczne wyznaczenie celów głównych i szczegółowych prowadzonych zajęć pozwala zwiększyć szanse na edukacyjny sukces, a wymiarze prywatnym - na zaspokojenie osobistych potrzeb. Sukcesy będą tym większe, im większa będzie wiara w możliwość opanowania przyswajanego materiału. Realizacja wyznaczonych małych celów powinna dawać poczucie sukcesu wzmacniającego motywację do dalszej nauki (tzw. metoda małych osiągnięć).

W odbiorze społecznym starość postrzegana jest raczej w kategoriach ubytku niż zysku. Warunkiem powodzenia i satysfakcji z podjętej w starszym wieku nauki jest natomiast pozytywny stosunek instruktorów do osób starszych. Na osobę w starszym wieku, podobnie jak na młodsze, należy patrzeć pozytywnie i optymistycznie. Nauczyciel ma wierzyć w swojego ucznia bez względu na jego wiek i widzieć to, co wciąż potrafi, a nie 
to, czego już więcej robić nie jest w stanie. W toku nauki udziela słów zachęty, aprobaty, pozytywnych komentarzy i wzmocnień. Jak wykazano, dla uzyskania zbliżonego poziomu poczucia skuteczności i osiągnięć starsi dorośli wymagają bardziej pozytywnych informacji zwrotnych w porównaniu z młodszymi dorosłymi (Mehrotra 2003). Nie mniej ważne jest afektywne i empatyczne podejście do uczestników, okazywanie radości ze spotkań, jak również rozbudzanie entuzjazmu towarzyszącego każdemu rozpoczęciu zajęć i oczekiwaniu na następne spotkanie.

\section{Zasada inkluzji}

W starszym wieku w aktywności edukacyjnej ludzie często szukają okazji do wzbogacenia życia towarzyskiego, nawiązania nowych znajomości i relacji społecznych. Socjalizacja stanowi dla nich ważny motyw przystąpienia do zajęć, w związku z czym, powinny one poza realizacją innych celów, wzmacniać więzi między członkami grupy. Socjalizacji będą służyć np.: praca w parach, w grupach, odpowiednio długie przerwy między zajęciami, zachęty do wymiany adresów i telefonów. Każdy uczestnik powinien być dostrzeżony i doceniony. Wyrazem inkluzji będzie zachowywanie rytuału indywidualnych przywitań i pożegnań każdego członka grupy, z czasem coraz bardziej emocjonalnych. Werbalna inkluzja polega np. na zwracaniu się do każdego uczestnika po imieniu. Niewerbalną inkluzję zapewnia kontakt wzrokowy czy dotyk (Gibson, Burnside 2005). Należy zatroszczyć się, aby instruktor był dobrze widziany przez wszystkich uczestników, czemu służy dobre oświetlenie pomieszczenia, unikanie ustawienia na tle okna czy formowanie grupy na planie koła.

\section{Zasada wzajemnego szacunku}

Zasada wzajemnego szacunku powinna być oczywista w każdej ludzkiej relacji, niemniej w edukacji osób starszych wymaga podkreślenia ze względu na nasilające się zjawisko ageizmu, które polega na negatywnych stereotypowych przekonaniach i postawach dyskryminujących seniorów ze względu na ich zaawansowany wiek (Kilian 2004). Każdy uczeń bez względu na liczbę przeżytych lat i stan funkcjonowania powinien być szanowany i doceniany. Wyrazem szacunku będzie cierpliwość okazywana seniorom znajdującym upodobanie w powtarzaniu tych samych historii. Pozbawiony uprzedzeń instruktor w zachowaniu tym będzie doszukiwał się głębszych znaczeń i okazji do lepszego poznania osoby, która wciąż odwołuje się do tych samych doświadczeń. Z szacunku dla seniorów będzie używał niewymuszonych zwrotów grzecznościowych, w przypadku popełniania błędów - delikatnie, bez oceniania i wywierania presji, zaproponuje lepsze rozwiązania. W kontaktach z osobami niepełnosprawnymi będzie zwracał się do nich bezpośrednio, a nie przez osoby trzecie lub pytał o przyzwolenie na nawiązanie kontaktu dotykowego, np. proponując osobie niewidomej pomoc przewodnika. W pełni zaakceptuje specyfikę funkcjonowania seniorów i dostosuje do niej proces nauczania i własne postępowanie. Jak wykazano, stosowanie metodyki pracy edukacyjnej specyficznej dla osób w starszym wieku pozwala wyeliminować w procesie uczenia się poczucie zagrożenia i frustracji (Corey 2004). Dobry nauczyciel uszanuje i uwypukli wartość wiedzy i doświadczenia zaawansowanych wiekowo uczestników, ich samych umiejscawiając w centrum procesu uczenia się. 
Poznanie specyfiki pracy edukacyjnej z osobami w starszym wieku oraz stosowanie się do jej zasad jest niezbędne dla zapewnienia efektywności prowadzonego szkolenia. Wyniki podjętej nauki mogą wykraczać poza określone cele w zakresie wiedzy czy umiejętności i wyrażać się w lepszym rozumieniu samego siebie, radzeniu sobie z wyzwaniami życiowymi, rozwijaniu własnych zainteresowań, refleksji nad życiem i zgromadzonym doświadczeniem, również w pozytywnym wpływie na zdrowie i zdolności umysłowe (Purdie, Boulton-Lewis 2003). W zaawansowanym wieku uczenie się pozwala na uzyskanie kontroli nad własnym życiem poprzez przystosowanie do zmian zachodzących we współczesnym świecie i osiągnięcie poczucia spełnienia (Glendenning, Battersby 1990). Rolą nauczycieli i instruktorów jest maksymalizowanie korzyści odnoszonych z edukacji prowadzonej w starszym wieku poprzez dostosowanie metodyki nauczania do rozpoznanych rzeczywistych możliwości i potrzeb seniorów.

\section{Bibliografia}

Birren J. K., Schaie K. W. (2001). Handbook of the psychology and aging. San Diego: Academic Press.

Brady E. M., Holt S. R., Welt B. (2003). Peer teaching in lifelong learning institutes. „Educational Gerontology”, nr 29(10), s. 851-868.

Corey G. (2004). Theory and practice of group counseling. Belmont: Brooks/Cole.

Delahaye B. L., Smith B. J. (1998). How to be an effective trainer. New York: Wiley.

Gibson F., Burnside I. (2005). Education and preparation for group work. W: Gibson F., Burnside I. (red.). Working with older adults. Group process and techniques. Boston: Jones \& Bartlett, s. 59-71.

Glendenning F., Battersby D. (1990). Educational gerontology and education for older adults: A statement of first principles. „Australian Journal of Adult and Community Education", nr 3o(1), s. 38-44.

Halicki J. (200o). Edukacja seniorów w aspekcie teorii kompetencyjnej. Studium historyczno-porównawcze. Białystok: Wydawnictwo Uniwersyteckie.

Jarvis P., Walker J. (1997). When the process becomes the product. Summer universities for seniors. „Education and Ageing”, nr 12(2), s. 6o-68.

Jarvis P. (2001). Learning in later life. London: Kogan Page.

Kilian M. (2004). Źródła ageizmu i jego przejawy we współczesnym świecie. „Gerontologia Polska", nr 12(3), s.125-128.

Kilian M. (2014). You learn through traveling, as you travel through learning. Modern education of the elderly provided by Elderhostel. W: Stawiak-Ososińska M., Chrost S. (red.). Situation, Education and Activation of Elderly People in Europe. Kielce: Agencja Reklamowa TOP, s. 223-233.

Kim A., Merriam S. B. (2004). Motivations for learning among older adults in a learning in retirement institute. „Educational Gerontology”, nr 30(6), s. 441-455.

Knowles M. S. (1980). The modern practice of adult education: From pedagogy to andragogy. Englewood Cliffs: Prentice Hall/Cambridge.

Knowles M. S., Holton E. F., Swanson R. A. (2009). Edukacja dorostych, Warszawa: Wydawnictwo Naukowe PWN. 
Lamdin L., Fugate M. (1997). Elderlearning. New frontier in an aging society, Phoenix: Oryx Press.

Lemieux A., Martinez M. S. (200o). Gerontagogy beyond words: A reality. „Educational Gerontology", nr 26(5), s. 475-498.

Mehrotra C. M. (2003). In defence of offering educational Programs for Older Adults. „Educational Gerontology”, nr 29(8), s. 645-655.

Park D. C. (1999). Cognitive aging, processing resources, and self-report. W: Schwarz N., Park D. C., Knauper B., Sudman S. (red.). Cognition, aging, and self-report. Philadelphia: Psychology Press, s. 45-69.

Percy K., Withnall A. (1994). Good practice in the education and training of older adults. Hampshire: Arena.

Purdie N., Boulton-Lewis G. (2003). The learning needs of older adults. „Educational Gerontology", nr 29(2), s. 129-149.

Sherron R. H., Lumsten D.B. (1990). Introduction to educational gerontology. Washington: Hemisphere.

Simson S., Thompson E., Wilson L. (2001). Who is teaching lifelong learners? A study of peer educators in Institutes for Learning in Retirement. "Gerontology \& Geriatrics Education", nr 22(1), s. 31-43.

Spigner-Littles D., Anderson C. E. (1999). Constructivism: A paradigm for older learners. „Educational Gerontology”, nr 25(3), s. 203-209.

Tabbutt-Henry J., Kahn K., Powell P. (2008). Adult Learner-Centered Training: An Introduction for Educators in Home and Residential Care. New York: Paraprofessional Healthcare Institute.

Tomporowski P. D. (2003). The psychology of skill: A lifespan approach. Westport: Praeger Publishers.

Whitbourne S. K., Slevin A. E. (1978). Imagery and sentence retention in elderly and young adults. „Journal of Genetic Psychology”, nr 133(2), s. 287-298.

Vakil E., Hoffman Y., Myzliek D. (1998). Active Versus Passive Procedural Learning in Older and Younger Adults. „Neuropsychological Rehabilitation”, nr 8(1), s. 31-41.

Wike V. S. (1994). Kant on Happiness in Ethics. Albany: State University of New York Press.

Yenerall J. D. (2003). Educating an aging society: The university of the third age in Finland. „Educational Gerontology”, nr 29(8), s. 703-716.

Zych A. (1999). Człowiek wobec starości. Szkice z gerontologii społecznej. Katowice: Wydawnictwo Śląsk.

\section{METHODOLOGICAL ASPECTS OF EDUCATION OF OLDER ADULTS. BASIC INSTRUCTIONS AND PRINCIPLES}

Abstract: The article discusses teaching methodology for older adults within: planning educational activities, defining its purposes, methods, contents, knowledge acquisition and learning progress evaluation. Special attention was paid to the formulated principles of teaching seniors. 
Key words: older age, older adults, teaching, methodology, didactic principles, education in older age, geragogy, gerontology

Marlena Kilian - doktor nauk humanistycznych, adiunkt na Wydziale Nauk Pedagogicznych Uniwersytetu Kardynała Stefana Wyszyńskiego w Warszawie. Obszary zainteresowań badawczych: gerontologia społeczna, tyflopedagogika, geragogika i geragogika specjalna. Adres do korespondencji: ul. Fredry 3, 05-092 Łomianki. Adres e-mail: m.kilian@uksw.edu.pl 